\title{
Effect of Plant Growth Regulators on Rooting Behavior of Stem Cuttings of Terminalia chebula (Retz.)
}

\author{
Bojja Harish Babu*, Amit Larkin and Hemant Kumar \\ College of Forestry, Sam Higginbottom University of Agricultural Technology \\ and Sciences, Allahabad U.P., India \\ *Corresponding author
}

\begin{tabular}{|l|}
\hline Key w or d s \\
Auxins, Clonal \\
multiplication, \\
Multipurpose tree, \\
Plus trees
\end{tabular}

A B S T R A C T

The effect of IBA and IAA (Auxins) concentrations were examined to mass multiply plus trees of Terminalia chebula (Retz.) through vegetative propagation via rooting of stem cuttings. The experiment was conducted in a completely randomized design (CRD) with three replications, One year old leafless branch cuttings were taken from selected superior phenotypes from the surrounding environs of SHUATS, Allahabad. Cuttings treated with 0, 500, 1000, 1500 and 2000ppm concentrations of Indole 3-Butyric acid (IBA) and Indole 3- Acetic acid (IAA) were planted in poly bags kept under a phyto-environmentally controlled mist chamber. A limited rooting was recorded in untreated cuttings (control), while rooting of cuttings of significantly increased with an increase in concentrations of IBA and IAA. Among two auxins tested, IBA was most effective in inducing rooting, sprouting and associated traits. Out of different concentrations, 2000ppm IBA concentration was found best and achieved over $70 \%$ rooting in cuttings. It also triggered more number of roots, higher root length, shoot proliferation, maximum shoot and root biomass. This paper discusses the role of growth regulators in influencing rooting of stem cutting and has practical implication for the development of protocol for asexual propagation and establishing clonal plantations of Terminalia chebula for promoting, increasing greenery and supply of timber.

\section{Introduction}

Terminalia chebula (Retz.) a member of combretaceae family popularly known as chebulic myrobylan is an economically important multipurpose tree widely distributed throughout South East Asia including India, Srilanka, Bhutan, Nepal, Bangladesh, Mynmar etc. In India it is found in the Sub Himalayan region from Ravi eastwards to West Bengal and Assam, Tamil nadu, common in Madras, Mysore and southern part of South India.
(Gupta et al., 2003) It is a large evergreen tree with spreading crown with drooping branches mostly found near moist tracts along the streams, river banks and occasionally in moist and dry tropical forest areas. All most all parts of tree like leaves, bark, flowers, fruits, wood and roots are useful for household, medicinal, Ayurvedic and industrial purposes. Terminalia chebula (Retz.) which exhibited a number of medicinal activities due to the presence of a large number of different types of phytoconstituents. The fruit of the tree 
possesses diverse health benefits and has been used as traditional medicine for household remedy against various human ailments since antiquity (Nayagam and Varghese, 2015; Rangsriwong et al., 2009). T. chebula has been extensively used in Ayurveda, Unani and Homoeopathic medicine and has become a cynosure of modern medicine. The powder of T. chebula fruits has been used in chronic diarrhea. It is used in nervous weakness, nervous irritability. It promotes the receiving power of five senses. It is adjuvant in hemorrhages due to its astringent nature and good for chronic cough, chorizo, sore throat as well as asthma. Also it is useful in renal calculi, dysurea, retention of urine and skin disorders with discharges like allergies, urticaria and other erythematous disorders (Bhardwaj et al., 1993; Swamy et al., 2002).

The fruits of $T$. chebula are rich in tannins (about 32\%-34\%) and its content varies with geographical distribution (Aslokar et al., 1992; Williumson, 2002). The tannins of $T$. chebula are of pyrogallol (hydrolysable) type. A group of researchers found 14 components of hydrolysable tannins (gallic acid, chebulagic acid, punicalagin, chebulanin, corilagin, neochebulinic acid, ellagic acid, chebulinic acid, 1,2,3,4,6-penta-O-galloyl- $\beta$ D-glucose, 1,6-di-o-galloyl-D-glucose, casuarinin, 3,4,6-tri-o-glloyl-D-glucose, terchebulin) from $T$. chebula fruits (Singh, 2001). Other constituents include phenolics such as chebulinic acid, ellagic acid and anthra quinones. Some of the other minor constituents were polyphenols such as corilagin, galloyl glucose, punicalagin, terflavin A, maslinic acid (Husen and Pal, 2006). Besides, fructose, amino acids, succinic acid, betasitosterol, resin and purgative principle of anthraquinone are also present (Choudhary et al., 2015; Gehlot et al., 2014). Flavonol, glycosides, triterpenoids, coumarin conjugated with gallic acids called chebulin as well as other phenolic compounds were also isolated (Husen and Pal, 2006; Nanda et al., 1973; Yoganarasimhan, 2000). Twelve fatty acids were isolated from $T$. chebula of which palmitic acid, linoleic acid and oleic acid were main constituents (Vander Krieken et al., 1993). The observed health benefits may be credited to the presence of the various phytochemicals like polyphenols, terpenes, anthocyanins, flavonoids, alkaloids and glycosides. It has immense economic importance in various industries viz., pharmaceutical, timber, paper, soap, match, food, fodder and fuel (Kumar et al., 2017). The wood has high calorific value, makes excellent firewood, and produces good quality charcoal for producer gas plants. Commercial exploitation of this plant is hampered by the shortage of superior planting stock, primarily due to the difficulties experienced in propagating species using the conventional method of multiplication by seeds due to poor seed viability, inadequate germination and lower survival under field conditions (Tubtimdee and Shotipruk, 2011). Moreover, Terminalia chebula is a cross pollinated species exhibit a wide variability in terms of growth and foliage quality. Vegetative techniques are used as indispensable tool for mass multiplication of superior phenotypes/genotypes and producing true to type uniform plants (Thakur et al., 2008). Rooting of stem cuttings is easiest and economical methods of vegetative propagation usually exploited in many tree species. Only a limited success was achieved in rooting of stem cuttings of Terminalia species and concluded as difficult to root genus (Leakey et al., 1982; Mewar and Naithani, 2016). Rooting of cuttings will be affected by age of the ortet, season and exogenous application of root promoting hormones. It is essential to understand the critical factors in influencing the rooting (Siddiqui and Hussain, 2007; Singh, 2001; Zhang et al., 1997). Therefore, an attempt was made in the present study to develop an efficient, economically viable and 
reproducible vegetative propagation protocol through stem cuttings for commercial propagation of selected phenotypes of $T$. chebula.

\section{Materials and Methods}

The experiment was carried out in the mist chamber of Forest Nursery, College of Forestry, Allahabad, SHUATS during 201718. The altitude of the study area is about 98 meters above mean sea level. The cuttings of Terminalia chebula were prepared from selected superior genotypes from the surrounding environs of Allahabad. Plus trees were selected on the basis of their phenotypically superior stems and crown characteristics and stature in the stand. One year old branch cuttings were taken from $15 \pm 5$ year- old selected trees during January. The leafless cuttings about $15 \pm 2.5 \mathrm{~cm}$ length and $1-2 \mathrm{~cm}$ in diameter having 4-5 buds were taken. The sharp Secateurs were used for preparation of cuttings. Cuttings were immediately placed in $10^{\circ} \mathrm{C}$ water to prevent desiccation. Mature cuttings were brought to laboratory and treated with $0,500,1000,1500$ and $2000 \mathrm{mg} \mathrm{L}^{-1}$ concentrations of Indole 3Butyric Acid (IBA) and Indole -3- Acetic Acid (IAA). The different IBA and IAA concentrations were prepared by dissolving the appropriate amount of IBA and IAA in 5$10 \mathrm{ml}$ of methanol and volume gradually made up to $1000 \mathrm{ml}$ with distilled water. The care was taken to prevent the precipitation of IBA and IAA during the process of dilution. The IBA and IAA solutions were transferred separately in to ten containers for giving treatments. The cuttings were divided in to nine groups and each group contained 27 cuttings, which were dipped in these nine solutions. The basal cut ends up to $2.5-\mathrm{cm}$ of cuttings was dipped in following concentrations of IBA and IAA for 24 hours duration. The upper cut ends of treated cuttings were sealed with inert paraffin wax to avoid desiccation through surface loss of water during rooting and also prevent fungal attack during continuous misting. The cuttings were planted immediately after treatment with IBA and IAA in the polythene bags filled with rooting medium. One-third length of the cuttings was inserted in the rooting medium and poly bag were arranged according to Completely Randomized Design (CRD). The basal ends of the cuttings were dipped in $0.2 \%$ Bavistin solution just before planting to prevent attack of pathogens. The observations on rooting, sprouting, root number, root length; root biomass and shoot biomass were recorded at 90 days after planting of cuttings. Data on rooting $\%$, and sprouting $\%$ did not follow normal distribution; therefore, arc sine transformation was employed. Similarly, data on root number and leaf number were also transformed using square root transformation method. The transformed data was subjected to analysis of variance as suggested by the statistical methods (Snedecor and Cochran, 1989). The significance of treatments was tested using $\mathrm{F}$ test.

\section{Results and Discussion}

Although, a limited rooting (10\%) was achieved in untreated cuttings, but the application of auxins (IBA and IAA) significantly $(\mathrm{P}<0.05)$ increased rooting in stem cuttings from $12 \%$ to $62 \%$. Lower concentrations of IBA and IAA $\left(500 \mathrm{mg} \mathrm{L}^{-1}\right)$ were also least effective and statistically at par with untreated cuttings. There is an overwhelming evidence that auxins promote rooting, which can be either naturally occurring within the plant (endogenous) or applied to the plant (exogenous) during vegetative propagation (Kumar et al., 2009; Siddiqui and Hussain, 2007; Singh, 2001). Synthetic auxins like IBA, IAA and NAA are most commonly used to promote root development in clonal propagation. Auxin promotes the starch hydrolysis and the 
mobilization of sugars and nutrients at the base of the cuttings during the regeneration of adventitious roots (Khare, 2007).

The present study revealed that IBA treatments were more efficient than IAA in inducing rooting of stem cuttings. Further, the rooting percent steadily increased with an increase in concentration of auxins from 500 $\mathrm{mg} \mathrm{L}^{-1}$ to $2000 \mathrm{mg} \mathrm{L}^{-1}$. These results are consistent and corroborated with the findings of earlier workers, who demonstrated that IBA was most effective auxin in triggering rooting in stem cuttings than IAA and NAA (CSIR, 2002; Jayaramkumar, 2006; Singh, 2001; Varier, 2002). IBA was quite strong auxin, while IAA is readily destroyed (Leopold, 1995). IBA may also enhance rooting via increased internal-free IBA, or may synergistically modify the action of IAA or the endogenous synthesis of IAA; IBA can enhance tissue sensitivity for IAA and increase rooting (CSIR, 2002). The effectiveness of higher concentrations of IBA and IAA on rooting (\%) in this study confirm that high auxin requirement to compensate the low endogenous levels of auxin in mature cuttings especially in difficult to root species. Terminalia chebula is difficult to root species (Leakey et al., 1982), as such it need higher concentrations of auxins for triggering rooting in stem cuttings. The auxin treatments significantly increased Rooting (\%), number of roots, root length, sprouting (Table 1). With the exogenous application of adequate IBA levels, the callus further differentiated into xylem leading to the production of roots.

In conclusion, the vascular differentiation of cells and formation of roots was taken directly with the use of higher concentrations of IBA and IAA in Teminalia spp, a difficult to root species, whereas the lower concentration ended with callusing and little differentiation in to roots. The number of roots increased from 6.06 to 15.95 per cutting and root length from 1.87 to $8.99 \mathrm{~cm}$ as the IBA concentration increased from 0 to $2000 \mathrm{mg} \mathrm{\textrm {L } ^ { - 1 }}$ concentration. The results are in conformity with the reports of earlier workers (Luna and Kumar, 2006), who stated that IBA treatments increased both rooting percent and root number in cuttings of Ficus spp. Several researchers also reported that exogenous application of auxin treatments especially IBA and IAA enhanced root proliferation and as well as root number in many species (Zhang et al., 1997; Kumar et al., 2009). Increase in length of the roots might be due to an early initiation of roots at higher concentrations of IBA and therefore more utilization of the nutrients due to early formation of the roots.

Fig.1 Effect of IBA concentrations (500ppm, 1000ppm, 1500ppm, 2000ppm on rooting (\%) of $T$. chebula
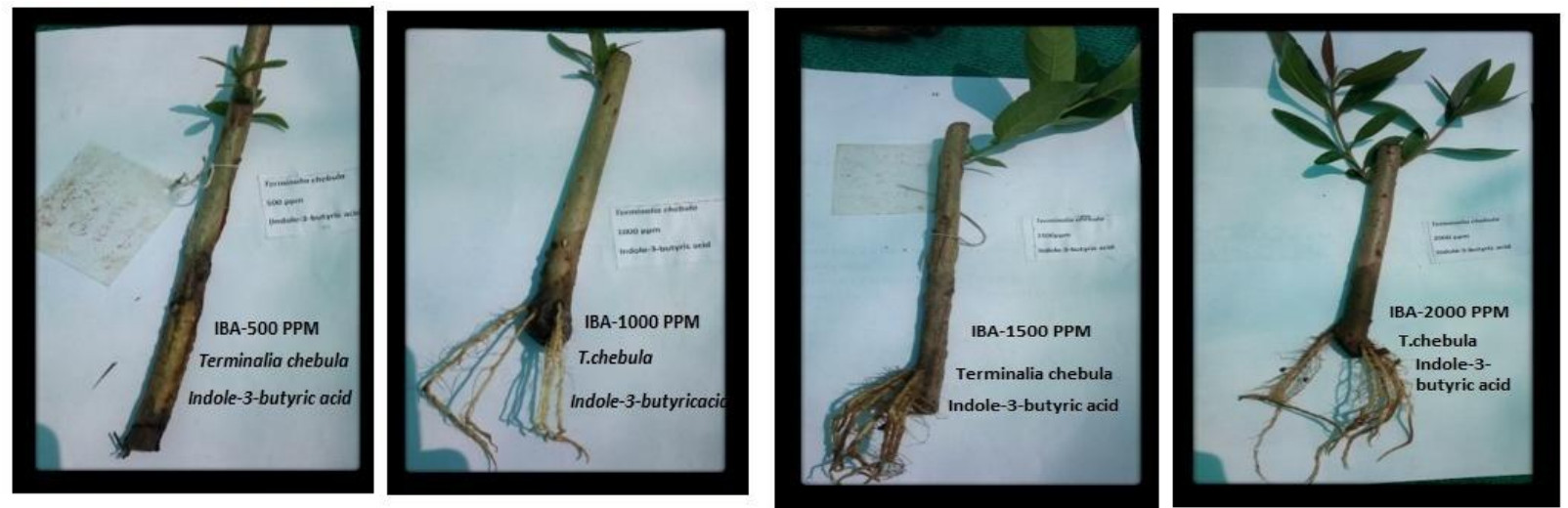
Fig.2 Effect of IAA concentrations (500ppm, 1000ppm, 1500ppm, 2000ppm on rooting (\%) of $T$. chebula
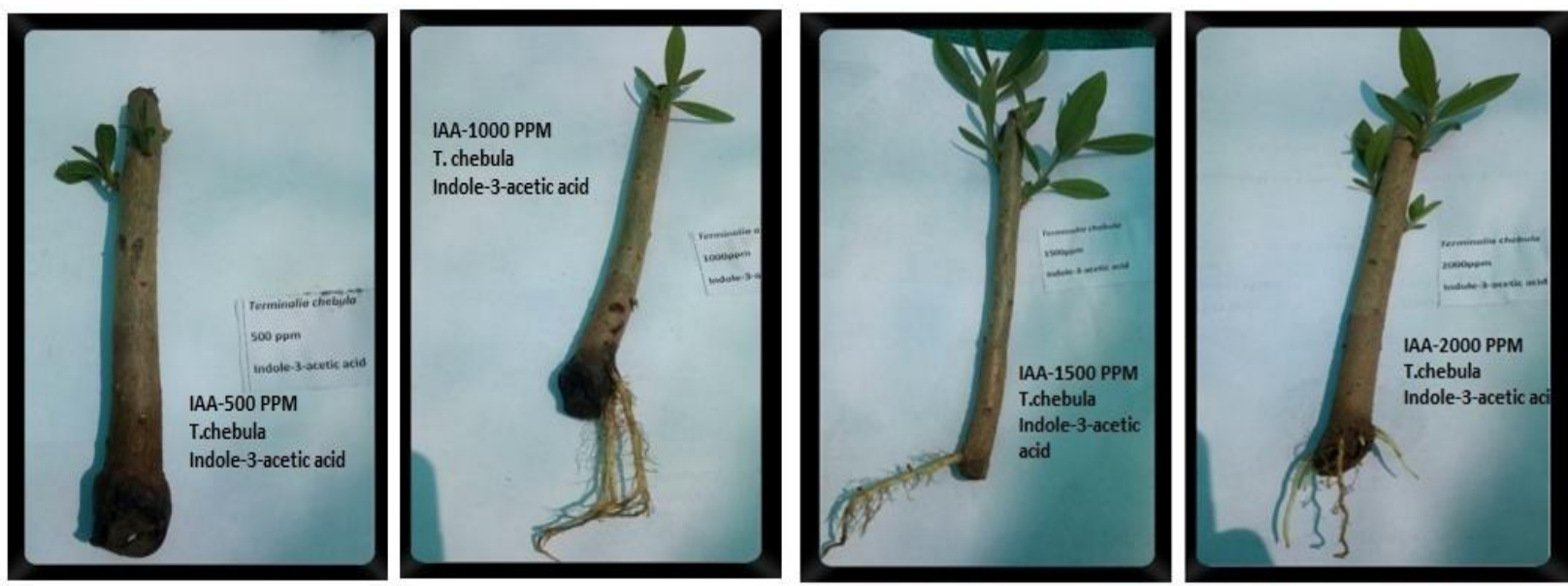

Fig.3 Effect of IBA and IAA concentrations on rooting and sprouting (\%) of T. chebula

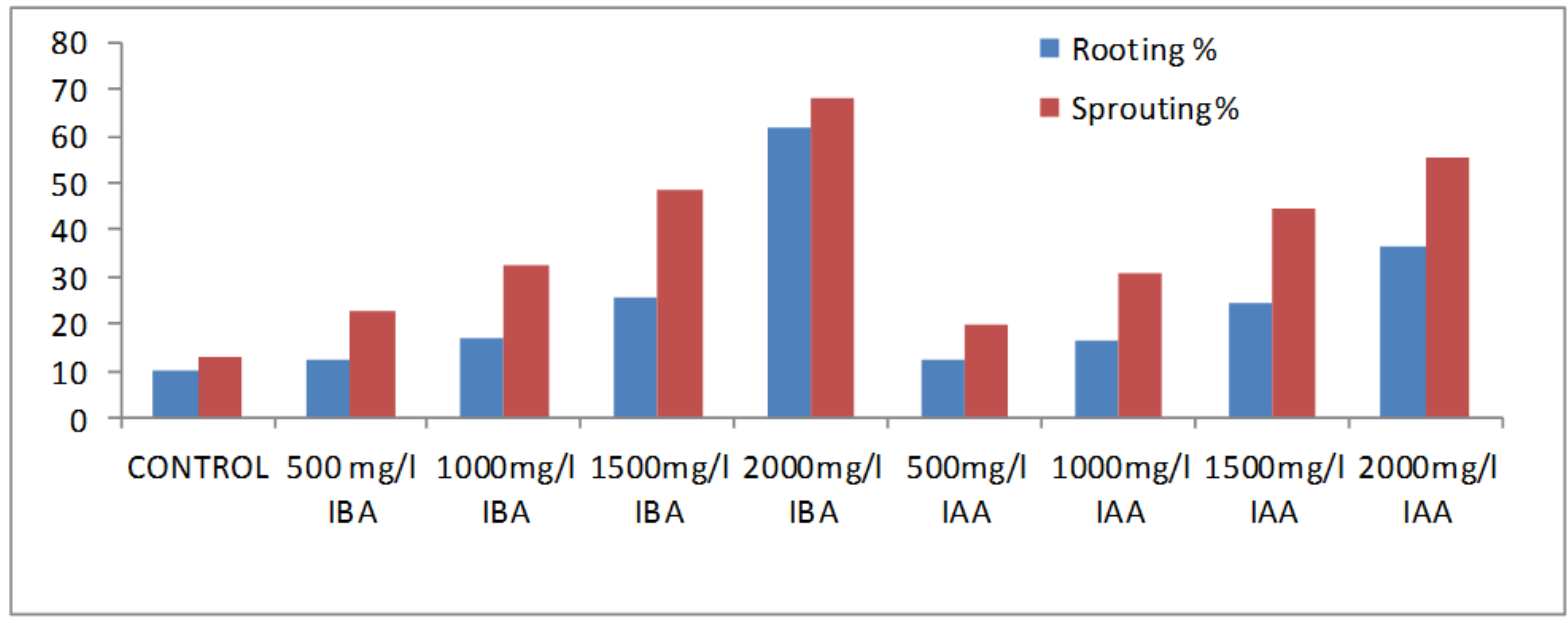

Fig.4 Effect of IBA and IAA concentrations on root biomass and shoot biomass of T.chebula

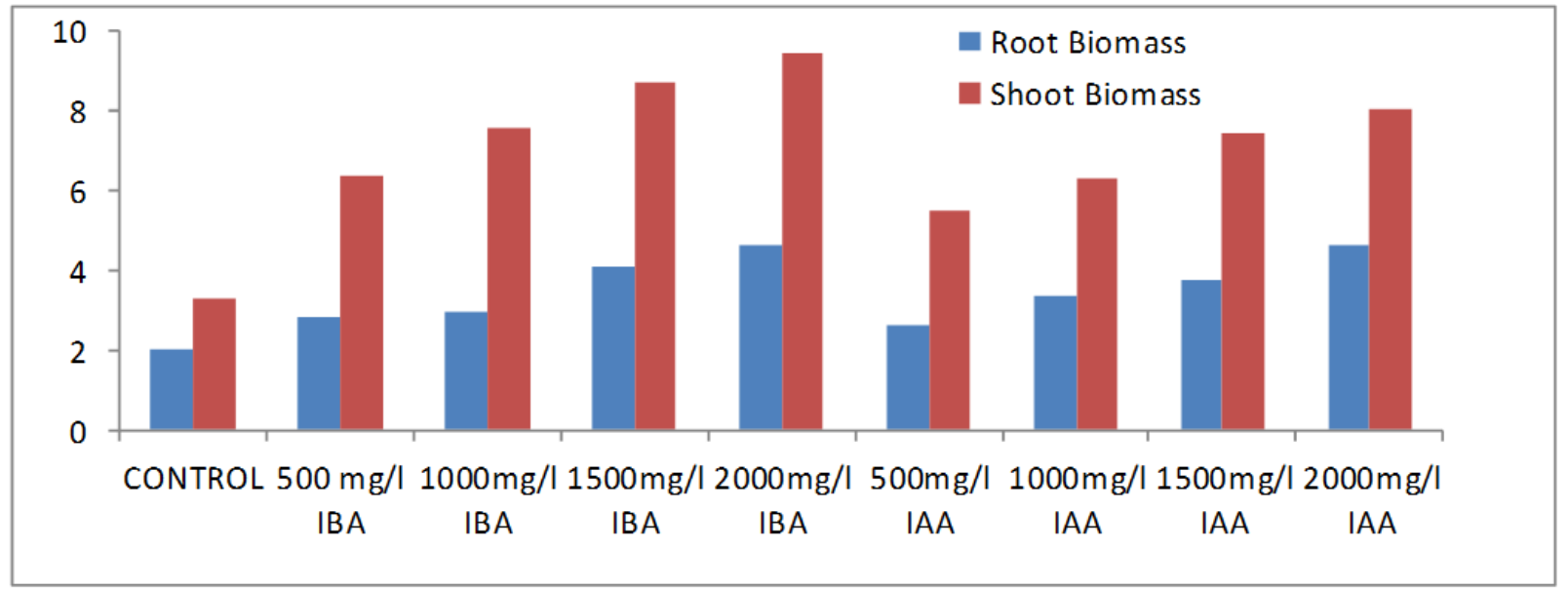


Table.1 Effect of different concentrations of IBA and IAA on rooting of stem cuttings of Terminalia chebula

\begin{tabular}{|c|c|c|c|c|c|c|c|}
\hline Treatments & $\begin{array}{l}\text { Rooting } \\
(\%)\end{array}$ & $\begin{array}{l}\text { Root } \\
\text { number }\end{array}$ & $\begin{array}{l}\text { Root } \\
\text { Length } \\
(\mathrm{cm})\end{array}$ & $\begin{array}{l}\text { Sprouting } \\
(\%)\end{array}$ & $\begin{array}{l}\text { Shoot length } \\
(\mathrm{cm})(90 \text { DAP) }\end{array}$ & $\begin{array}{l}\text { Root } \\
\text { Biomass (g) }\end{array}$ & $\begin{array}{l}\text { Shoot } \\
\text { Biomass (g) }\end{array}$ \\
\hline Control(water) & 10.01 & 6.06 & 1.87 & 12.80 & 6.09 & 1.98 & 3.26 \\
\hline IBA $500 \mathrm{mg} \mathrm{L}^{-1}$ & 12.66 & 7.38 & 3.32 & 22.79 & 11.79 & 2.82 & 6.34 \\
\hline IBA $1000 \mathrm{mg} \mathrm{L}^{-1}$ & 17.12 & 9.25 & 4.55 & 32.31 & 13.91 & 2.94 & 7.56 \\
\hline IBA $1500 \mathrm{mg} \mathrm{L}^{-1}$ & 25.75 & 12.84 & 7.01 & 48.83 & 17.91 & 4.06 & 8.67 \\
\hline IBA $2000 \mathrm{mg} \mathrm{L}^{-1}$ & 61.74 & 15.95 & 8.99 & 68.11 & 21.23 & 4.63 & 9.41 \\
\hline IAA $500 \mathrm{mg} \mathrm{L}^{-1}$ & 12.53 & 7.87 & 2.20 & 19.90 & 10.79 & 2.58 & 5.50 \\
\hline IAA $1000 \mathrm{mg} \mathrm{L}^{-1}$ & 16.35 & 8.14 & 2.71 & 30.71 & 12.80 & 3.35 & 6.30 \\
\hline IAA $1500 \mathrm{mg} \mathrm{L}^{-1}$ & 24.43 & 9.13 & 3.73 & 44.63 & 14.72 & 3.73 & 7.42 \\
\hline IAA $2000 \mathrm{mg} \mathrm{L}^{-1}$ & 36.50 & 10.38 & 6.46 & 55.56 & 17.22 & 4.59 & 8.00 \\
\hline F Test & S & $\mathrm{S}$ & $\mathrm{S}$ & $\mathrm{S}$ & S & $\mathrm{S}$ & $\mathrm{S}$ \\
\hline $\mathrm{SE}( \pm)$ & 1.207 & 0.508 & 0.361 & 0.473 & 0.501 & 0.435 & 0.360 \\
\hline CD at $0.05 \%$ & 2.555 & 1.075 & 0.764 & 1.001 & 1.052 & 0.920 & 0.763 \\
\hline
\end{tabular}

The sprouting (\%) and shoot Length of stem cuttings increased with an increase in concentrations of IBA and IAA (Fig, 3 and 4). A significantly higher $\%$ of sprouting i.e. $68.11 \%$ and $55.56 \%$ were found in cuttings treated with $2000 \mathrm{mg} \mathrm{L}^{-1}$ treatments of IBA and IAA, respectively. The lowest sprouting (\%) was recorded in untreated stem cuttings (control). However, there were no significant differences observed between 500 and 1000 $\mathrm{mg} \mathrm{L}^{-1}$ treatments of IBA, 1000 and $1500 \mathrm{mg}$ $\mathrm{L}^{-1}$ IBA. The maximum sprouting and shoot length in cuttings of T.chebula with higher concentration of IBA and IAA treatments in the present study might be ascribed to better root growth which augmented absorption and translocation of nutrients from soil which take active part in various plant metabolic processes. Rooting in T.chebula with high concentrations of IBA and IAA might lead to advanced bud break and maximum rooting and sprouting resulted in better shoot proliferation. Moreover, the root and shoot growth are intricately linked to endogenous levels of hormones and food materials. (Khare, 2007) A significantly higher shoot biomass $9.41(\mathrm{~g})$ and $8.00(\mathrm{~g})$ was achieved in cuttings treated with $2000 \mathrm{mg} \mathrm{L}^{-1}$ IBA and IAA, respectively (Fig. 1). Similarly, high root biomass of $4.63 \mathrm{~g}$ and $4.59 \mathrm{~g}$ was recorded in cuttings treated with $2000 \mathrm{mg} \mathrm{L}^{-1}$ IBA and IAA, respectively (Fig. 2 and 4). Increase in root-shoot biomass due to exogenous application of auxins in cuttings is not extraordinary phenomenon as several workers reported such sort of results in different species (Khare, 2007; Zhang et al., 1997). The high root biomass is attributed to higher number of roots and more root length in cuttings treated with auxin (IBA and IAA) at higher concentrations, whereas lower number of roots and small length of roots resulted in lower biomass in untreated and low auxin concentrations. Increase in shoot biomass is a consequence of higher sprouting and more number of leaves induced in auxin treated cuttings especially at high concentrations, whereas a very low sprouting and limited number of leaves resulted in low shoot biomass in cuttings under control and lower concentrations of auxin treatments. The present findings are in line with findings of 
other workers (Zhang et al., 1997; Kumar et al., 2009).

The present study concludes that there were significant differences recorded between different concentrations of Auxins on rooting behavior. The study evolved an effective and rapid cutting propagation protocol for mass multiplication of Terminalia chebula. IBA2000mg $\mathrm{L}^{-1}$ concentration is recommended to achieve maximum rooting in stem cuttings for efficient rooting during vegetative propagation in Terminalia chebula. It is also suggested to plant cuttings during spring season under phyto-environmentally controlled mist chamber; it will be possible to produce over eighty percent of rooting in stem cuttings, which can be an asset for establishing clonal plantations of T.chebula.

\section{References}

Aslokar LV, Kakkar KK, Chakre OJ. New Delhi: Publications and Information's Directorate, CSIR; 1992. Glossary of Indian medicinal plants with active principles.

Bhardwaj S.D., Chakraborty A.K. and Joshi N.K. (1993) Ind. For., 119(5), 360-366.

Choudhary M., Jaiswal S., Singh R., Arya I.D. and Arya S. (2015) Adv. For. Sci., 2(1), 1-6.

CSIR. The wealth of India - A dictionary of Indian raw materials and industrial products. Vol X. New Delhi: Publication and Information Directorate, CSIR; 2002. pp. 522-524.

Gehlot A., Gupta R.K., Tripathi A., Arya I. and Arya S. (2014) Adv. in For. Sci., 1(1), 106-115.

Gupta AK, Tandon N, Sharma M. Quality standards of Indian medicinal plant. New Delhi: Indian Council of Medical Research; 2003. pp. 207-209.

Hartmann H.T., Kester D.E., Davies F.T. Jr. and Geneve R. L. (2011) Plant propagation: principles and practices, 8thedn. New York: Prentice-Hall, Sao Paulo, p. 915.

Husen A. and Pal, M. (2006) New For., 31, 57-73.

Jayaramkumar K. Effect of geographical variation on content of tannic acid, gallic acid, chebulinic acid, and ethyl gallate in Terminalia chebula fruits. Nat Prod. 2006; 2(3-4): 170-175.

Khare CP. Indian medicinal plants: An illustrated dictionary. Berlin: SpringerVerlag; 2007. pp. 652-653.

Kumar A, Lakshman K, Jayaveera K, Satish K, Tripathi SM. Estimation of rutin and quercetin Terminalia chebula by HPLC. Int J AesthAntiag Med. 2009; 2(1):3.

Kumar, H., S.B. Lal, A.M. Wani, Rajiv Umrao, Neelam Khare and Neeta Shweta Kerketta. 2017. Seed Size Correlates with Germination Traits in Terminalia Arjuna Genotypes. Int.J.Curr.Microbiol.App.Sci. $\quad 6(8)$ : 2896-2903. doi: https://doi.org/ 10.20546/ijcmas.2017.608.346

Leakey, R.R.B., Chapan V.R. and Longman K.A. (1982) For. Ecol \& Mang., 4(3), 53-56.

Leopold A.C. (1995) Auxins and plant growth substances Berkeley and Losangels. Univ. California, p. 327-377.

Luna R.K. and Kumar S. (2006) J. For. Sci. 12 (132), 207-2015.

Mewar D. and Naithani D.C. (2016) Plant Archives, 16(2), 959-962.

Nanda K. K., Kumar P. and Kochar V.K. (1973), New Zealand J. For. Sci., 4 (2), 338-346.

Nayagam J.R. and Varghese K.I. (2015) Int. J. Curr. Agril.Res., 4(10), 14548.

Rangsriwong P, Rangkadilok N, Satayavivad J, Goto M, Shotipruk A. Subcritical water extraction of polyphenolic compounds from Terminalia chebula Retz. fruits. Sep Puri Tech. 2009; 66: 51-56. 
Siddiqui, M.I., and Hussain S.A. (2007) J. Agri., 23(4), 919-925.

Singh K.S. (2001) Int. J. Curr.Microbiol. App. Sci., 6(2), 1173-1178.

Snedecor G.W., and Cochran W.G. (1989) Statistical Methods, Eighth Edition, Iowa State University Press.

Swamy S.L., Puri S., Singh A.K. (2002) New For., 23, 143-147.

Thakur M, Rana RC, Thakur S. Physiochemical evaluation of Terminalia chebula fruits. $\mathbf{J}$ Non Timber Forest Prod. 2008; 15: 37-42.

Tubtimdee C, and Shotipruk A. Extraction of phenolics from Terminalia chebula Retz. with water-ethanol and waterpropylene glycol and sugaring-out concentration of extracts. Sep Puri Tech. 2011; 77(3): 339-346.
Vander Krieken W.M., Breteler H., Visser, M.H.M. and Mavridou D. (1993) Plant Cell Rep., 12,203-206.

Varier. A dictionary of Indian raw materials and industrial products. New Delhi: Publications and Information Directorate, Council of Scientific and Industrial Research; 2002. p. 387.

Williumson EN. Major herbs of Ayurveda. London: Churchill Livingstone; 2002. p. 299.

Yoganarasimhan SN. Medicinal plants of India. Bangalore: Self Publication; 2000. p. 541.

Zhang X, Chen C, He S, Ge F. Supercritical$\mathrm{CO}_{2}$ fluid extraction of the fatty oil in Terminalia chebula and GC-MS analysis. Zhong Yao Cai. 1997; 20(9): 463-464.

\section{How to cite this article:}

Bojja Harish Babu, Amit Larkin and Hemant Kumar. 2018. Effect of Plant Growth Regulators on Rooting Behavior of Stem Cuttings of Terminalia chebula (Retz.). Int.J.Curr.Microbiol.App.Sci. 7(08): 2475-2482. doi: https://doi.org/10.20546/ijcmas.2018.708.250 